\title{
Inhibitory effect of voluntary running wheel exercise on the growth of human pancreatic Panc-1 and prostate PC-3 xenograft tumors in immunodeficient mice
}

\author{
XI ZHENG ${ }^{1}$, XIAO-XING CUI ${ }^{1}$, MOU-TUAN HUANG ${ }^{1}$, YUE LIU ${ }^{1}$, WEICHUNG JOE SHIH ${ }^{2,3}$, \\ YONG LIN ${ }^{2,3}$, YAO PING LU ${ }^{1}$, GEORGE C. WAGNER ${ }^{4}$ and ALLAN H. CONNEY ${ }^{1,3}$ \\ ${ }^{1}$ Susan Lehman Cullman Laboratory for Cancer Research, Department of Chemical Biology, \\ Ernest Mario School of Pharmacy, Rutgers, The State University of New Jersey, Piscataway, NJ 08854; \\ ${ }^{2}$ Department of Bistatistics, School of Public Health, University of Medicine and Dentistry of New Jersey; \\ ${ }^{3}$ Cancer Institute of New Jersey, New Brunswick, NJ 08903; ${ }^{4}$ Department of Psychology, Rutgers, \\ The State University of New Jersey, Piscataway, NJ 08854, USA
}

Received December 21, 2007; Accepted January 25, 2008

\begin{abstract}
In the present study, we investigated the effect of voluntary exercise on the formation and growth of the human pancreas Panc-1 and prostate PC-3 tumors in immunodeficient mice. Female severe combined immunodeficient (SCID) mice were injected subcutaneously with human pancreatic cancer Panc-1 cells, and male SCID mice were injected subcutaneously with human prostate cancer PC-3 cells. Voluntary running wheel exercise for 63 days, starting one week before the subcutaneous injection of Panc-1 or PC-3 tumor cells into SCID mice, suppressed the growth of Panc-1 and PC-3 tumors. The exercise regimen increased the food and fluid consumption in the female and male mice. Exercise also decreased the size of the parametrial fat pads in the female mice and the paradidymis fat pads in the male mice, but there was no effect on the body weight. Mechanistic studies showed that voluntary running wheel exercise inhibited proliferation as reflected by a decreased mitosis, and the exercise regimen also stimulated apoptosis as reflected by the increased caspase- 3 (active form) expression in the Panc-1 and PC-3 tumors. Voluntary running wheel exercise decreased the ratio of the percent mitotic cells/ apoptotic cells in Panc-1 and PC-3 tumors by 38 and 32\%, respectively. The present study demonstrated an inhibitory effect of voluntary exercise on the growth of pancreas and prostate tumors in a SCID mouse xenograft model.
\end{abstract}

Correspondence to: Dr Allan H. Conney, Susan Lehman Cullman Laboratory for Cancer Research, Department of Chemical Biology, Ernest Mario School of Pharmacy, Rutgers, The State University of New Jersey, 164 Frelinghuysen Road, Piscataway, NJ 08854, USA

E-mail: aconney@rci.rutgers.edu

Key words: exercise, cancer prevention, apoptosis, mitosis, cancer growth

\section{Introduction}

Pancreatic and prostate cancers are leading causes of death in the USA. Cancer of the pancreas ranks fourth among USA cancer deaths (males and females), and the five-year survival is $<5 \%$ (1) whereas prostate cancer ranks second among USA cancer deaths in males (after lung) (1). Attempts to inhibit the formation or treat these cancers are important goals of the cancer research community. Studies in experimental animals indicate an inhibitory effect of voluntary exercise on colon, breast, skin and pancreatic carcinogenesis (2-7). However, to the best of our knowledge no studies exist on the effect of exercise on prostate carcinogenesis or on the growth of prostate or pancreas tumors.

Epidemiological studies on the relationship between physical activity and prostate cancer risk have been inconclusive (8-11), but large population-based studies suggest that physical exercise is associated with a reduced risk of advanced prostate cancer and prostate cancer death $(12,13)$. In additional studies, the serum from men who exercise inhibited the growth and increased apoptosis in prostate cancer LNCaP cells $(14,15)$. Although the results of epidemiologal studies regarding a possible association between physical activity and pancreatic cancer risk are inconclusive (16-18), laboratorybased studies demonstrated that voluntary exercise reduced the growth of preneoplastic pancreatic foci and inhibited azaserine-induced pancreas carcinogenesis in Lewis and F344 rats $(6,7)$.

The present study was undertaken to determine the effects of voluntary running wheel exercise on the formation and growth of the human pancreatic Panc-1 and androgenindependent prostate PC-3 xenograft tumors in SCID mice. Our study showed that voluntary running wheel exercise inhibited the growth of the pancreas Panc-1 and prostate PC-3 tumors in SCID mice. Mechanistic studies showed that voluntary running wheel exercise inhibited proliferation and stimulated apoptosis in these tumors. 


\section{Materials and methods}

Cell culture and reagents. Panc-1 cells were kindly provided by Dr Pamela Crowell (Indiana University-Purdue University Indianapolis, IN). PC-3 cells were obtained from the American Type Culture Collection (ATCC, Rockville, MD, USA). Matrigel was obtained from BD Biosciences (Bedford, MA). RPMI-1640 and DMEM tissue culture media, penicillinstreptomycin, L-glutamine and fetal bovine serum (FBS) were from Gibco (Grand Island, NY). Panc-1 cells were maintained in DMEM, and PC-3 cells were maintained in RPMI-1640 culture medium. DMEM and RPMI media contained $10 \%$ FBS and were supplemented with penicillin $(100 \mathrm{U} / \mathrm{ml})$-streptomycin $(100 \mu \mathrm{g} / \mathrm{ml})$ and L-glutamine (300 $\mu \mathrm{g} / \mathrm{ml})$. Cultured cells were grown at $37^{\circ} \mathrm{C}$ in a humidified atmosphere of $5 \% \mathrm{CO}_{2}$ and were passaged twice a week.

The formation and growth of Panc-1 and PC-3 tumors in immunodeficient mice with or without voluntary running wheel exercise. SCID mice (6-7 weeks old) were obtained from Taconic Farms Inc. (Germantown, NY). The animals were housed in sterile filter-capped microisolator cages and provided with sterilized food (laboratory rodent diet 5010) and water. Female mice were injected subcutaneously with Panc-1 cells $\left(2 \times 10^{6}\right.$ cells $/ 0.1 \mathrm{ml} /$ mouse $)$ suspended in $50 \%$ matrigel in DMEM medium, and male mice were injected subcutaneously with PC- 3 cells $\left(2 \times 10^{6}\right.$ cells $/ 0.1 \mathrm{ml} /$ mouse $)$ suspended in $50 \%$ matrigel in RPMI-1640 medium. In the experiment with Panc- 1 cells, 12 female mice were placed in cages equipped with running wheels ( 6 mice/cage) and 10 female mice were placed in cages with no running wheels (5 mice/cage) one week before the tumor cell inoculation. In the experiment with PC-3 cells, 12 male mice were placed in cages equipped with running wheels and 12 male mice were placed in cages with no running wheel one week before the tumor cell inoculation (6 mice/cage). The running wheel mice had free access to the wheel $24 \mathrm{~h}$ /day during the whole experimental period (63 days). The running wheels had digital counters that measured the running wheel revolutions (5). Tumor size measurements were started on day 21 after the tumor cell injection. Tumor size was measured by determining the length and width (expressed as $\mathrm{cm}^{2}$ ) once per week until the end of the experiment. Body weight was also measured once every week. The animal experiments were carried out under an Institutional Animal Care and Use Committee (IACUC)approved protocol.

Determination of mitotic cells. Panc-1 and PC-3 tumors in the mice from each experimental group were excised. The samples were fixed overnight in $10 \%$ formalin and then transferred to $70 \%$ ethanol. Paraffin-embedded tissue sections of $5-\mu \mathrm{m}$ thickness were stained with hematoxylin and eosin (H\&E). Mitotic cells were counted under a light microscope as described elsewhere (19).

Caspase-3 (active form) immunostaining. An antibody that reacts with the active form of caspase- 3 was purchased from R\&D Systems (Catalog number: AF835). Tumor sections used for the measurement of caspase-3 (active form) were stained with the horseradish peroxidase-conjugated avidin method with some modification (20). Briefly, sections were incubated with caspase-3 primary antibody (1:2.000 dilution) for $30 \mathrm{~min}$ at room temperature followed by incubation with a biotinylated anti-rabbit secondary antibody for $30 \mathrm{~min}$ and incubation with conjugated-avidin solution (ABC Elite kit purchased from Vector Laboratories) for $30 \mathrm{~min}$. Color development was achieved by incubation with $0.02 \% 3,3^{\prime}-$ diaminobenzidine tetrahydrochloride containing $0.02 \%$ hydrogen peroxide for $10 \mathrm{~min}$ at room temperature. The slides were then counterstained with hematoxylin, dehydrated and coverslips were added for permanent mounting. A positive reaction was shown as a brown precipitate in the cytoplasm and/or perinuclei of the cells. The percent of caspase- 3 positive cells was determined in each tumor.

Statistical analyses. The Student's t-test was used to determine the differences for percent mitotic cells, percent caspase- 3 positive cells and the ratio of percent mitotic cells/ caspase- 3 positive cells between the running and non-running wheel groups. The analyses of the increase in tumor size were based on the mixed effect regression (repeated measurement) model (21). The treatment effects were assessed by comparing the rates of change over time between the treatment groups (i.e. comparing the slopes between the groups).

\section{Results}

Effects of voluntary running wheel exercise on the consumption of food and water in SCID mice. In female mice injected with Panc- 1 cells, the running wheel group consumed $21 \%$ more food and $23 \%$ more water versus the mice in the non-running wheel group (Table I). The average distance the mice ran on the running wheel was $1.09 \pm 0.16 \mathrm{miles} / \mathrm{mouse} /$ day (Table I). In the experiment with PC-3 cells in the male mice, the running wheel group consumed $26 \%$ more food and $22 \%$ more water versus the mice in the non-running wheel group (Table I). The average distance the mice ran in the running wheel group was $1.38 \pm 0.21 \mathrm{miles} / \mathrm{mouse} /$ day (Table I).

Effects of voluntary running wheel exercise on body weight and tissue fat in SCID mice. Running wheel exercise had no effect on body weight in the mice injected with Panc-1 or PC-3 cells. However, there was a $30 \%$ decrease in the weight of the parametrial fat pads in the female mice injected with Panc- 1 cells and a $32 \%$ decrease in the weight of paradidymis fat pads in the male mice injected with PC-3 cells (Table II).

Effects of voluntary running wheel exercise on the growth of Panc- 1 and PC-3 tumors in SCID mice. Cells (2x10 6 Panc- 1 or PC-3) were injected subcutaneously into SCID mice as described in Fig. 1. Voluntary running wheel exercise delayed the formation of Panc-1 tumors in some of the mice. The mice in the control group formed a measurable tumor by 21 days after the injection of Panc-1 cells while $17 \%$ of the mice in the running wheel group were tumor-free at this time. Eight percent of the animals in the running wheel group remained tumor-free at 42 days after the injection of Panc-1 cells but the mice had a tumor by 49 days.

The growth of Panc-1 tumors was measured in 10 control and 12 running wheel mice. In the control group, the 10 mice 
Table I. The effects of voluntary exercise on the food and fluid consumption in SCID mice.

\begin{tabular}{lcccc}
\hline Group & $\begin{array}{c}\text { Gender/no. } \\
\text { of mice }\end{array}$ & $\begin{array}{c}\text { Food consumption } \\
\text { (g/mouse/day) }\end{array}$ & $\begin{array}{c}\text { Fluid consumption } \\
\text { (ml/mouse/day) }\end{array}$ & $\begin{array}{c}\text { Running distance } \\
\text { (miles/mouse/day) }\end{array}$ \\
\hline Panc-1 & F/10 & $3.83 \pm 0.08$ & $4.32 \pm 0.09$ & - \\
Control & F/12 & $4.62 \pm 0.09^{\mathrm{a}}$ & $5.29 \pm 0.10^{\mathrm{a}}$ & $1.09 \pm 0.16$ \\
Running wheel & & & $5.50 \pm 0.11$ & - \\
PC-3 & $\mathrm{M} / 12$ & $4.54 \pm 0.12$ & $6.69 \pm 0.09^{\mathrm{a}}$ & $1.38 \pm 0.21$ \\
Control & $\mathrm{M} / 12$ & $5.71 \pm 0.10^{\mathrm{a}}$ & & \\
Running wheel & & & & \\
\hline
\end{tabular}

Female (F) SCID mice were injected with human pancreatic cancer Panc- 1 cells $\left(2.0 \times 10^{6}\right.$ cells/mouse). Male (M) SCID mice were injected with human prostate cancer PC-3 cells $\left(2.0 \times 10^{6}\right.$ cells/mouse). Twelve female and 12 male mice were placed in cages (6 mice/cage) equipped with running wheels ( 1 running wheel/cage) one week before the injection of tumor cells and remained until the end of the study (56 days after the tumor cell injection). Wheel revolutions and the consumption of food and fluid were recorded. Each value represents the mean \pm SE. The Student's t-test was used to determine the difference between the control and running wheel group, ${ }^{a} \mathrm{p}<0.001$.

Table II. The effects of voluntary exercise on body weight and parametrial/paradidymis fat pads in SCID mice.

\begin{tabular}{|c|c|c|c|c|}
\hline Group & $\begin{array}{l}\text { Gender/no. } \\
\text { of mice }\end{array}$ & $\begin{array}{l}\text { Initial and final body } \\
\text { weight ( } \mathrm{g} / \text { mouse })\end{array}$ & $\begin{array}{l}\text { Parametrial }(\mathrm{F}) \text { or paradidymis } \\
\text { (M) fat pads (g/mouse) }\end{array}$ & $\begin{array}{l}\text { Percentage decrease } \\
\text { in fat pad weight }\end{array}$ \\
\hline
\end{tabular}

\section{Panc-1}

Control

$\mathrm{F} / 10$

Running wheel

$\mathrm{F} / 12$

$22.6 \pm 0.30$

$24.2 \pm 0.40$

$22.2 \pm 0.29$

$23.5 \pm 0.48$

PC-3

Control

$\mathrm{M} / 12$

$26.2 \pm 0.74$

$28.0 \pm 0.49$

Running wheel

$\mathrm{M} / 12$

$26.3 \pm 0.53$
$0.33 \pm 0.03$

$0.23 \pm 0.02^{\mathrm{a}}$

30.3

$27.9 \pm 0.65$

Body weights of female (F) and male (M) SCID mice in the experiments described in Table I were measured. Parametrial fat pads from the female mice and paradidymis fat pads from the male mice were weighed. Each value represents the mean \pm SE. The Student's t-test was used to determine the difference between the control and running wheel group, ${ }^{\mathrm{a}} \mathrm{p}<0.05$ and ${ }^{\mathrm{b}} \mathrm{p}<0.01$.

had a measurable tumor on day 21 . The tumor size was determined on days $21,28,35,42,49$ and $58(\mathrm{~N}=10$ on each day). In the running wheel group, not all of the animals had a tumor at 21 days after the injection of Panc-1 cells. Thus the tumor size was measured on day $21(\mathrm{~N}=10)$; days 28,35 and $42(\mathrm{~N}=11)$; and on days 49 and $56(\mathrm{~N}=12)$ (Fig. 1A). From the fitted regression equations, the rates of tumor growth between days 21 and 56 were $0.00654 \mathrm{~cm}^{2}$ per day for the control group, and $0.00476 \mathrm{~cm}^{2}$ for the running wheel group. This implied that, on average, the rate of tumor growth for the control group was $0.00179 \mathrm{~cm}^{2}$ per day faster than that for the running wheel group per day (the difference was significant with $\mathrm{p}=0.0331$ ). The difference in tumor size between the control and the running wheel groups increased from 0.0930 to $0.156 \mathrm{~cm}^{2}$ from day 21 to 56 . The differences were statistically significant at the $5 \%$ level beginning on day 28 $(p \leq 0.0069)$. At the end of the experiment, the average tumor size per mouse (length $\mathrm{x}$ width, $\mathrm{cm}^{2}$ ) was $0.51 \pm 0.03$ for the control group and $0.35 \pm 0.02$ for the running wheel group (Fig. 1). A statistical analysis using the Student's t-test showed that the difference for tumor size between the control and running wheel groups at the end of the study was statistically significant $(\mathrm{p}<0.001)$. Running wheel exercise had no effect on body weight throughout the study (data not shown).

Although running wheel exercise did not delay the formation of PC-3 tumors measured at 21 days, it suppressed the growth of PC-3 tumors in the mice (Fig. 1B). From fitted regression equations, the rates of tumor growth between days 21 and 56 were $0.00537 \mathrm{~cm}^{2}$ per day for the control group and $0.00263 \mathrm{~cm}^{2}$ for the running wheel group (10 mice/group). This implied that, on average, the rate of PC-3 tumor growth for the control group was $0.00274 \mathrm{~cm}^{2}$ per day faster than 
A

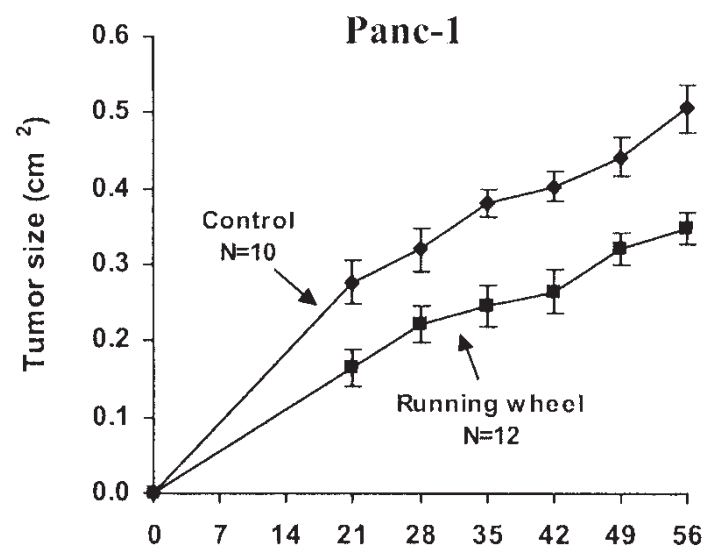

Days after injection of tumor cells
B

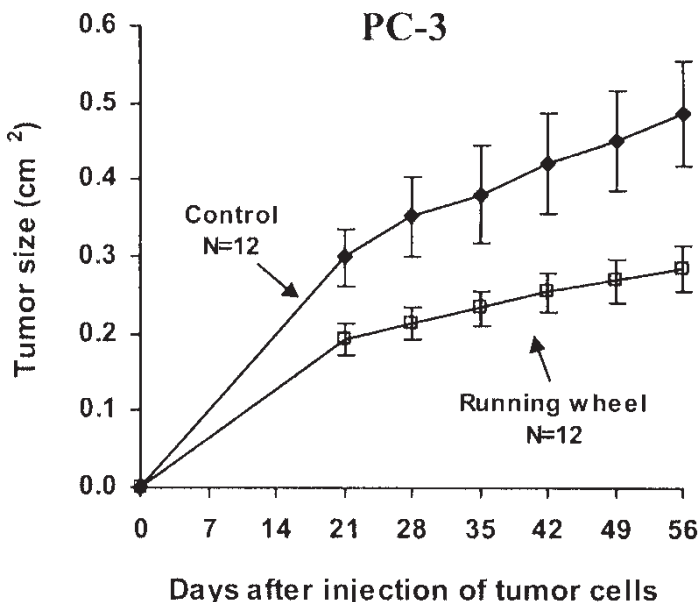

Figure 1. The effect of voluntary exercise on the growth of pancreas Panc-1 and prostate PC-3 tumors in SCID mice. Female SCID mice were injected subcutaneously with human pancreatic cancer Panc-1 cells $\left(2.0 \times 10^{6}\right.$ cells/mouse), and male SCID mice were injected subcutaneously with human prostate cancer PC-3 cells $\left(2.0 \times 10^{6}\right.$ cells/mouse). The male and female mice were randomly assigned into two groups. One group was placed in cages (5-6 mice/cage) equipped with running wheels ( 1 running wheel/cage) one week before the injection of tumor cells, and the running wheels remained until the end of the study (56 days after the tumor cell injection). Mice in another group were in cages without a running wheel (5-6 mice/cage). Starting at day 21 after the tumor cell injection, tumor size (length $\mathrm{x}$ width, $\mathrm{cm}^{2}$ ) per mouse was measured once a week until the end of the experiment. (A) The tumor size was measured in the control group for the 10 tumors on each day as indicated. In the running wheel group, tumor size was measured on day 21 ( $N=10$ ); days 28, 35 and 42 ( $N=11$ ); and on days 49 and $56(\mathrm{~N}=12)$. (B) The tumor size was measured in the control and running wheel groups in the 10 tumors on each day as indicated. Each value represents the mean $\pm \mathrm{SE}$.

Table III. The effects of voluntary exercise on the percent of mitotic and caspase- 3 positive cells in pancreas Panc- 1 and prostate PC-3 tumors.

\begin{tabular}{|c|c|c|c|c|c|}
\hline Group & $\begin{array}{l}\text { Gender/ } \\
\text { no.of } \\
\text { mice }\end{array}$ & $\begin{array}{l}\text { Percent } \\
\text { mitotic } \\
\text { cells }\end{array}$ & $\begin{array}{l}\text { Percent of } \\
\text { caspase-3 } \\
\text { positive cells }\end{array}$ & $\begin{array}{c}\text { Ratio of percent } \\
\text { mitotic cells/caspase-3 } \\
\text { positive cells }\end{array}$ & $\begin{array}{l}\text { Percent decrease in } \\
\text { ratio of mitotic/ } \\
\text { apoptotic cells }\end{array}$ \\
\hline
\end{tabular}

Panc-1

Control

$\mathrm{F} / 10$

$0.55 \pm 0.03$

$0.40 \pm 0.03$

$1.43 \pm 0.13$

Running wheel

$\mathrm{F} / 12$

$0.43 \pm 0.02^{\mathrm{b}}$

$0.49 \pm 0.02^{\mathrm{a}}$

$0.89 \pm 0.05^{c}$

37.8

PC-3

Control

$\mathrm{M} / 12$

$0.47 \pm 0.02$

$0.35 \pm 0.02$

$1.37 \pm 0.07$

Running wheel

$\mathrm{M} / 12$

$0.38 \pm 0.02^{\mathrm{a}}$

$0.42 \pm 0.02^{\mathrm{a}}$

$0.93 \pm 0.05^{\mathrm{c}}$

32.1

Tumors from female (F) and male (M) SCID mice in the experiments described in Table I were fixed in formalin and processed for paraffin sections. Mitotic cells were identified and counted in H\&E stained sections using a light microscope. Caspase-3 positive cells were identified immunohistochemically. Each value represents the mean \pm SE. The Student's t-test was used to determine the difference between the control and running wheel groups; ${ }^{\mathrm{a}} \mathrm{p}<0.05,{ }^{\mathrm{b}} \mathrm{p}<0.01$ and ${ }^{\mathrm{c}} \mathrm{p}<0.001$.

that for the running wheel group per day (the difference was significant with $\mathrm{p}=0.0065$ ). On average, the difference in tumor size between the control and running wheel groups increased from 0.106 to $0.202 \mathrm{~cm}^{2}$ from day 21 to 56 . The differences were statistically significant at the $5 \%$ level beginning on day $28(\mathrm{p}<0.0388)$. At the end of the experiment, the average tumor size per mouse was $0.49 \pm 0.07 \mathrm{~cm}^{2}$ for the control group and $0.28 \pm 0.03 \mathrm{~cm}^{2}$ for the running wheel group (Fig. 1). A statistical analysis using the Student's t-test showed that the difference in tumor size between the control and running wheel group was statistically significant $(\mathrm{p}<0.05)$. There was no significant difference in the body weight between the control and running wheel group throughout the study (data not shown).

Effects of voluntary running wheel exercise on mitosis and apoptosis in Panc-1 and PC-3 tumors. The effects of voluntary running wheel exercise on the proliferation and apoptosis in Panc- 1 and PC-3 tumors described in Fig. 1 were studied by determining the percentage of mitotic cells and caspase- 3 
(active form) positive cells in these tumors. As shown in Table III, the percentage of mitotic cells was decreased and the percentage of apoptotic cells was increased in Panc- 1 and PC-3 tumors in mice with running wheel exercise versus the control group. Running wheel exercise decreased the ratio of the percent mitotic cells/caspase-3 (active form) positive cells in Panc- 1 and PC-3 tumors by 38 and $32 \%$, respectively (Table III). Our results indicate a shift in the balance between cell proliferation and death towards a decreased tumor growth. Similar results were obtained when data from the two animals that developed a measurable pancreas tumor only after 21 days, post-tumor cell injection, were excluded from the analysis.

\section{Discussion}

In the present study, we demonstrated for the first time that voluntary running wheel exercise inhibited the growth of the human pancreatic and prostate tumors in immunodeficient SCID mice, and these effects of exercise were paralleled by a decreased proliferation and an increased apoptosis. In a previous study, it was found that voluntary running wheel exercise suppressed the size and growth rate of azaserineinduced preneoplastic pancreatic foci in rats (6). Voluntary running wheel exercise was also found to inhibit the formation of N-nitrosomethylurea-induced mammary cancer (3) and the formation of azoxymethane-induced colon cancer (2) in rat models. In addition, Welsch and colleagues found that voluntary running wheel exercise reduced the growth of breast xenograft tumors in athymic mice (22). However, these earlier studies did not examine the effects of voluntary exercise on apoptosis in preneoplastic or tumor cells. Recent studies showed that voluntary exercise inhibited UVB-induced carcinogenesis, enhanced UVB-induced apoptosis in the epidermis and also enhanced apoptosis in UVB-induced tumors but not in the non-irradiated normal epidermis or in the epidermis away from the tumors in tumor-bearing mice $(5,23)$.

The mechanisms by which voluntary exercise inhibits the growth and stimulates apoptosis in tumor cells are not known. Voluntary exercise is known to modify circulating growth factors and cytokines such as insulin-like growth factor 1, interleukins 6 and 10, and leptin $(10,12,24)$. Recent in vitro studies showed that the serum from the men who exercised inhibited the growth and stimulated apoptosis in cultured human prostate cancer LNCaP cells $(14,15)$. We have obtained similar results using serum from exercising mice (unpublished observation). Further studies are needed to determine if exercise-induced growth inhibition and enhanced apoptosis in Panc- 1 and PC-3 tumors are mediated by cytokines that are modulated by running wheel exercise in SCID mice.

Although there were no differences in body weight between the mice in the running wheel and non-running wheel control groups, tissue fat was decreased in mice with access to running wheels versus the mice without such access (Table II). A recent study showed that voluntary running wheel exercise inhibited UVB-induced skin carcinogenesis and decreased the weight of the parametrial fat pads and the thickness of the dermal fat layer in SKH-1 mice (5). The surgical removal of the parametrial fat pads (partial lipectomy) two weeks prior to UVB irradiation enhanced UVB-induced apoptosis (23) suggesting that fat cells secrete substances that inhibit apoptosis in cells with DNA damage and possibly in tumors. Further studies are needed to determine whether the exerciseinduced decrease in tissue fat plays a role in the exerciseinduced inhibition of Panc-1 and PC-3 tumor growth. In epidemiological studies, exercise was reported to be associated with a decreased risk of advanced prostate cancer $(12,13,25)$. Additional studies are needed to determine whether exercise decreases the risk or growth of pancreatic cancer in humans.

\section{Acknowledgements}

The present study was supported in part by grants from the National Institutes of Health (CA 121391-01 and CA092268). The authors thank Ms. Florence Florek for her excellent help in the preparation of this manuscript.

\section{References}

1. Jemal A, Siegel R, Ward E, Murray T, Xu J and Thun MJ: Cancer statistics, 2007. CA Cancer J Clin 57: 43-66, 2007.

2. Reddy BS, Sugie S and Lowenfels A: Effect of voluntary exercise on azoxymethane-induced colon carcinogenesis in male F344 rats. Cancer Res 48: 7079-7081, 1988.

3. Cohen LA, Choi K, Backlund JY, Harris R and Wang CX: Modulation of $\mathrm{N}$-nitrosomethylurea induced mammary tumorigenesis by dietary fat and voluntary exercise. In Vivo 5: 333-344, 1991.

4. Thompson HJ: Effects of physical activity and exercise on experimentally-induced mammary carcinogenesis. Breast Cancer Res Treat 46: 135-141, 1997.

5. Michna L, Wagner GC, Lou YR, Xie JG, Peng QY, Lin Y, Carlson K, Shih WJ, Conney AH and Lu YP: Inhibitory effects of voluntary running wheel exercise on UVB-induced skin carcinogenesis in SKH-1 mice. Carcinogenesis 27: 2108-2115, 2006.

6. Roebuck BD, McCaffrey J and Baumgartner KJ: Protective effects of voluntary exercise during the postinitiation phase of pancreatic carcinogenesis in the rat. Cancer Res 50: 6811-6816, 1990 .

7. Craven-Giles T, Tagliaferro AR, Ronan AM, Baumgartner KJ and Roebuck BD: Dietary modulation of pancreatic carcinogenesis: calories and energy expenditure. Cancer Res 54: S1964-S1968, 1994

8. Cerhan JR, Torner JC, Lynch CF, Rubenstein LM, Lemke JH, Cohen MB, Lubaroff DM and Wallace RB: Association of smoking, body mass, and physical activity with risk of prostate cancer in the Iowa 65+ Rural Health Study (USA). Cancer Causes Control 8: 229-238, 1997.

9. Wannamethee SG, Shaper AG and Walker M: Physical activity and risk of cancer in middle-aged men. Br J Cancer 85: 1311-1316, 2001.

10. Lee IM, Sesso HD, Chen JJ and Paffenbarger RS Jr: Does physical activity play a role in the prevention of prostate cancer? Epidemiol Rev 23: 132-137, 2001.

11. Friedenreich CM, McGregor SE, Courneya KS, Angyalfi SJ and Elliott FG: Case-control study of lifetime total physical activity and prostate cancer risk. Am J Epidemiol 159: 740-749, 2004.

12. Patel AV, Rodriguez C, Jacobs EJ, Solomon L, Thun MJ and Calle EE: Recreational physical activity and risk of prostate cancer in a large cohort of US men. Cancer Epidemiol Biomarkers Prev 14: 275-279, 2005.

13. Nilsen TI, Romundstad PR and Vatten LJ: Recreational physical activity and risk of prostate cancer: A prospective populationbased study in Norway (the HUNT study). Int J Cancer 119: 2943-2947, 2006.

14. Leung PS, Aronson WJ, Ngo TH, Golding LA and Barnard RJ: Exercise alters the IGF axis in vivo and increases p53 protein in prostate tumor cells in vitro. J Appl Physiol 96: 450-454, 2004.

15. Ornish D, Weidner G, Fair WR, Marlin R, Pettengill EB, Raisin CJ, Dunn-Emke S, Crutchfield L, Jacobs FN, Barnard RJ, Aronson WJ, McCormac P, McKnight DJ, Fein JD, Dnistrian AM, Weinstein J, Ngo TH, Mendell NR and Carroll PR: Intensive lifestyle changes may affect the progression of prostate cancer. J Urol 174: 1065-1069, 2005. 
16. Michaud DS, Giovannucci E, Willett WC, Colditz GA, Stampfer MJ and Fuchs CS: Physical activity, obesity, height and the risk of pancreatic cancer. JAMA 286: 921-929, 2001.

17. Stolzenberg-Solomon RZ, Pietinen P, Taylor PR, Virtamo J and Albanes D: A prospective study of medical conditions, anthropometry, physical activity and pancreatic cancer in male smokers (Finland). Cancer Causes Control 13: 417-426, 2002.

18. Sinner PJ, Schmitz KH, Anderson KE and Folsom AR: Lack of association of physical activity and obesity with incident pancreatic cancer in elderly women. Cancer Epidemiol Biomarkers Prev 14: 1571-1573, 2005.

19. Tannapfel A, Geissler F, Kockerling F, Katalinic A, Hauss J and Wittekind C: Apoptosis and proliferation in relation to histopathological variables and prognosis in hepatocellular carcinoma. J Pathol 187: 439-445, 1999.

20. Zheng X, Chang RL, Cui XX, Avila GE, Lee S, Lu YP, Lou YR, Shih WJ, Lin Y, Reuhl K, Newmark H, Rabson A and Conney AH: Inhibitory effect of 12-O-tetradecanoylphorbol13-acetate alone or in combination with all-trans-retinoic acid on the growth of $\mathrm{LNCaP}$ prostate tumors in immunodeficient mice. Cancer Res 64: 1811-1820, 2004.
21. Lindsey JK: Models for Repeated Measurements. Claredon Press, Oxford, 1993.

22. Welsch MA, Cohen LA and Welsch CW: Inhibition of growth of human breast carcinoma xenografts by energy expenditure via voluntary exercise in athymic mice fed a high-fat diet. Nutr Cancer 23: 309-318, 1995.

23. Lu YP, Lou YR, Nolan B, Peng QY, Xie JG, Wagner GC and Conney AH: Stimulatory effect of voluntary exercise or fat removal (partial lipectomy) on apoptosis in the skin of UVB light-irradiated mice. Proc Natl Acad Sci USA 103: 16301-16306, 2006.

24. Pedersen BK and Fischer CP: Beneficial health effects of exercise - the role of IL- 6 as a myokine. Trends Pharmacol Sci 28: 152-156, 2007.

25. Giovannucci EL, Liu Y, Leitzmann MF, Stampfer MJ and Willett WC: A prospective study of physical activity and incident and fatal prostate cancer. Arch Intern Med 165: 1005-1010, 2005. 